\title{
НАУКОВО-МЕТОДИЧНЕ ЗАБЕЗПЕЧЕННЯ ОСВІТНЬОГО ПРОЦЕСУ У ВИЩОМУ ЮРИДИЧНОМУ НАВЧАЛЬНОМУ ЗАКЛАДІ
}

Стаття присвячена теоретичному обтрунтуванню особливостей науковометодичного забезпечення освітнього процесу у вищому юридичному навчальному закладі. Представлений авторський підхід до розуміння ключового поняття. Проаналізовані чинники, щчо детермінують появу методичного забезпечення нового покоління. Встановлені рівні науково-методичного забезпечення в залежності від суб'єктів творення. Автор репрезентує власну класифікацію видів науково-методичного забезпечення, щзо є актуальним для вищих юридичних навчальних закладів.

Ключові слова: освітній прочес; науково-методичне забезпечення; вищий юридичний навчальний заклад; Закон України «Про вищу освіту».

Загальна постановка проблеми. Діалектика розвитку вищої освіти передбачає поступове ускладнення технологій підготовки фахівців, що включає в себе не тільки застосування інноваційних методик проведення аудиторних занять, але i насамперед - технологій науково-методичного забезпечення освітнього процесу. Цей аспект діяльності у педагогічній науці останнім часом набув бурхливого розвитку в контексті застосування у навчальному процесі комп“ютерних технологій, проте в основі проектування і реалізації професійної освіти мають бути наукові концепції загального розуміння вектору руху.

Аналіз публікацій. 3 позицій педагогіки вищої школи як окремої галузі педагогічної науки питання науково-методичного забезпечення навчального процесу знайшли своє відображення у працях М.В.Буланової-Топоркової, Є.Ю.Владимирської, Л.І.Даниленко, 3.Н.Курлянд, В.М.Нагаєва, І.П.Підласого, Ю.Г.Фокіна, Д.В.Чернилевського та ін. Запровадження кредитно-модульної системи організації навчального процесу призвело до необхідності розробки теоретико-практичних засад науково-методичного забезпечення із врахуванням нової специфіки. Через це наукові розвідки Л.В.Васильченко, С.М.Гончарова, В.М.Нагаєва, В.О.Радкевича, Г.І.Руденка та ін. надали традиційним підходам нових граней.

Узагальнення поглядів вчених дає підстави констатувати, що науковометодичне забезпечення $\epsilon$ невід‘ємною складовою усього навчального процесу i спрямовано на виконання таких функцій, як: проективна, змістовно-організаційна, діагностична, контрольно-коригувальна тощо.

Виділення не вирішених раніше частин загальної проблеми. Разом 3 тим, слід зазначити, що на теперішній час відсутні дослідження, в яких би містилася класифікація елементів науково-методичного забезпечення, здійснювався системний підхід до їхнього аналізу. Фрагментарним є й аналіз чинників, що впливають на розвиток цього виду освітньої діяльності. Поза увагою науковців залишилися й питання особливостей науково-методичного забезпечення освітнього процесу у вищих юридичних навчальних закладах. 
Метою статті $€$ наукове обгрунтування специфіки науково-методичного забезпечення вищого юридичного навчального закладу на підставі структурного підходу. Досягнення поставленої мети стає можливим за умови розв'язання наступних завдань: 1 . Надати авторський підхід до розуміння поняття «науково-методичне забезпечення освітнього процесу», а також визначити чинники, що впливають на необхідність появи науковометодичного забезпечення нового покоління. 2. Встановити рівні науковометодичного забезпечення в залежності від суб'єктів їх творення. 3. Надати авторську класифікацію видів науково-методичного забезпечення. 4. Репрезентувати специфіку науково-методичного забезпечення вищого юридичного навчального закладу.

Виклад основного матеріалу дослідження. Ефективність процесу підготовки кадрів залежить від низки взаємопов'язаних педагогічних умов, що створені у певному вищому навчальному закладі. Особливе місце серед цих умов посідає науково-методичне забезпечення освітнього процесу. Під ним ми пропонуємо розуміти комплекс інформаційних матеріалів (текстових, графічних, медійних), які забезпечують потребу суб' єктів освітнього процесу у відомостях, що становлять цілепокладання й зміст освіти, і спрямованих на оптимальне досягнення кінцевих результатів навчання.

Слід зазначити, що на рівні дисертаційних досліджень питання науковометодичного забезпечення освітнього процесу у вищих навчальних закладах майже не вивчалося. Фрагментарно воно представлено у наукових доробках Є. Владимирської [1], Т. Годованюк [2], О. Павленко [3], А. Пуліної [4], Г. Савченко [5], Ю.Юрченка [6] та ін. У такий спосіб певною мірою охоплені окремі специфічні особливості науково-методичного забезпечення $\mathrm{y}$ педагогічних, технічних, медичних університетах, а також вищих навчальних закладах, в яких здійснюється підготовка й підвищення кваліфікації фахівців банківської та митної справи. Щодо підготовки юристів, то слід зазначити, що опис науково-методичного забезпечення на рівні дисертаційних досліджень $є$ достатньо аморфним і не структурованим. Достатньо навести цитату 3 автореферату дисертації на здобуття доктора педагогічних наук Г.Х.Яворської: «Науково-методичне забезпечення організації навчальновиховного процесу, спрямованого на формування соціально-професійної зрілості курсантів, потребує спеціальних навчальних посібників, методичних рекомендацій, дидактичного забезпечення для науково-педагогічних працівників вищих навчальних закладів МВС України, оскільки більшість 3 них не має педагогічної освіти.» [7, с.5]

Фрагментарним є й аналіз чинників, що впливають на розвиток цього виду освітньої діяльності. Тож в якості головних чинників, що впливають на подальший розвиток науково-методичного забезпечення освітнього процесу, зумовлюють необхідність появи забезпечення нового покоління, на наш погляд, слід виділяти наступні:

- бурхливий розвиток інформаційних технологій, що ініціює появу нової освітньої парадигми, запровадження не передбачуваних раніше форм навчання (наприклад, дистанційної і комбінованої освіти); 
- широко розповсюдження індивідуальних інформаційних пристроїв (нетбуків, планшетів, смартфонів), які можуть активно застосовуватися в освітніх цілях;

- актуалізація педагогічних досліджень щодо можливостей використання новітніх освітніх технологій;

- поетапна імпліментація до вітчизняних вищих навчальних закладів моделей навчання, притаманних західним вишам;

- поступове впровадження елементів індивідуалізації навчання, частковий відхід від тотальної стандартизації;

- зростання питомої ваги самоосвіти;

- поява поряд із традиційною (формальною освітою) альтернативних форм здобуття знань 3 метою підвищення професійної кваліфікації, зокрема MOOC (Massive open online couses) - масових відкритих он-лайн курсів, які створюються провідними університетами світу, нерідко на безоплатних засадах;

- можливості візуалізації навчального матеріалу через відповідні презентації, 3-D проектування, що дозволяє максимально спиратися на індивідуальні психологічні особливості особистості (наприклад, домінування зорової пам'яті);

- поширення кола працівників вищих навчальних закладів, які працюють над науково-методичним забезпеченням.

Безумовно, наведений нами перелік чинників не є вичерпним, проте й він свідчить про необхідність трансформації ідеології навчання. Це пов'язано, перш за все, із поступовим відходом від розуміння освіти як власне трансляції знань викладачем під час занять з подальшою перевіркою засвоєння матеріалу.

Тож можна констатувати, що науково-методичне забезпечення, яке знаходиться під значним впливом екстрапедагогічних i внутрішньопедагогічних факторів, стає основним знаряддям, яке дозволяє (за умови науково обгрунтованого його застосування) вищому навчальному закладу багатократно збільшити ефективність освітньої діяльності й стати конкурентоспроможнім на рівні держави.

Разом $з$ тим, розмитість концептуальних засад у питанні суті науковометодичного забезпечення освітнього процесу у вищих юридичних навчальних закладах спонукає нас до деталізації структури цього компоненту педагогіки і представити його авторське бачення.

Наша позиція полягає в тому, що науково-методичне забезпечення, яке поглинає в себе навчально-методичне забезпечення, слід розглядати на трьох взаємопов'язаних рівнях: нормативному (регламентація у Законі України «Про вищу освіту», у відповідних нормативно-правових актах Міністерства освіти i науки України, а також міністерств, що мають у своєму підпорядкуванні галузеві вищі навчальні заклади); науковому (у працях вчених, які розробляють дану проблематику); практичному (безпосередня реалізація вказаних видів забезпечення навчального процесу). 
Згідно зі ст.9 Закону України «Про вищу освіту» до стандартів освітньої діяльності відносяться кадрове, навчально-методичне, матеріально-технічне та інформаційне забезпечення освітнього процесу вищого навчального закладу i наукової установи. Зазначається, що «стандарти освітньої діяльності розробляються для кожного рівня вищої освіти в межах кожної спеціальності...» [8] У розділі V зазначеного Закону «Забезпечення якості вищої освіти» у ст.16 з-поміж іншого вказується на необхідність забезпечення наявності необхідних ресурсів для організації освітнього процесу, у тому числі самостійної роботи студентів, за кожною освітньою програмою. Таким чином, на законодавчому рівні встановлюється взаємний зв'язок методичного забезпечення та якості вищої освіти.

На превеликий жаль, у період після прийняття Закону України «Про вищу освіту» на рівні Міністерства освіти і науки України не з'явилося підзаконних актів, які б спрямували виші до удосконалення науковометодичного забезпечення. Посилаючись на проголошену вказаним Законом автономію вищих навчальних закладів, МОН України переклав усю нормативну базу щодо підготовки i запровадження будь-яких видів методичного забезпечення на самі виші.

Проте керівникам вищих навчальних закладів, особливо юридичного профілю, не завжди вистачає систематизованих педагогічних знань. У зв'язку 3 цим, вважаємо, стане в пригоді створена нами класифікація елементів науково-методичного забезпечення освітнього процесу. Пропонуємо виділяти наступні компоненти:

- проективні науково-методичні документи: професіограма, кваліфікаційна характеристика, освітньо-кваліфікаційна характеристика, освітньо-професійна програма підготовки фахівця; варіативна частина державного стандарту;

— нормативні науково-методичні документи: положення про вищий навчальний заклад, положення про організацію навчального процесу, типове положення про кафедру, положення про організацію практик і стажувань студентів, положення про кваліфікаційну роботу, положення про методику оцінювання якості вищої освіти, методичні рекомендації щодо особливостей організації навчального процесу у певному ВНЗ тощо;

- планові науково-методичні документи: навчальний план, робочі навчальні плани, графік навчального процесу, тематичні плани, розклади занять та заліково-екзаменаційних сесій;

- документи науково-методичного супроводження навчального nроцесу: навчальні (робочі навчальні) програми навчальних дисциплін; навчально-методичні комплекси дисциплін; плани-конспекти занять; фондові лекції; мультимедійні презентації; навчальні підручники i посібники; матеріали практичного спрямування для використання у ділових іграх, при ситуативному навчанні, використанні кейс-методу, тренінгів тощо; методичні рекомендації щодо організації індивідуальної та самостійної роботи студентів; тематика курсових, дипломних, магістерських робіт; матеріали проміжного й підсумкового контролю; 
- документи наочності: зразки документації у певній галузі (наприклад, макети кримінальних справ, процесуальні документи тощо).

У зв'язку із розгалуженістю науково-методичного забезпечення навчального процесу вважаємо за потрібне ввести до обігу додаткові видові поняття, зокрема виділити: нормативно-методичне, організаційно-методичне, предметно-методичне, інформаційно-методичне (з включенням до нього бібліотечно-методичного), виробничо-методичне забезпечення.

Розглянемо можливості втілення запропонованої моделі на прикладі вищого юридичного навчального закладу. При цьому беремо до уваги такі аспекти:

- мета певного виду науково-методичного забезпечення;

- укладачі;

- нормативна регламентація виду науково-методичного забезпечення;

- ступінь імперативності документів;

- період дії;

- процедури запровадження;

- безпосереднє застосування у навчальному процесі.

Нормативно-методичне забезпечення створюється на основі тих документів, які ми у своїй авторській класифікації віднесли до проективних і нормативних науково-методичних. Розробляються вони 3 метою стандартизації навчання, отримання відповідних ліцензій МОН України на здійснення освітньої діяльності, а також для забезпечення повноцінного цілеспрямованого функціонування вищого навчального закладу. Укладачами $\epsilon$ тимчасові робочі групи, до складу яких входять керівники і найбільш досвідчені працівники вищого навчального закладу, представники професійних «гільдій». Цей процес регламентується Законами України «Про освіту», «Про вищу освіту», в окремих випадках - «Про національну поліцію», «Про Національне антикорупційне бюро», «Про прокуратуру» та ін., відповідними нормативними актами Міністерства освіти і науки України. Нормативно-методичне забезпечення характеризується обов'язковістю виконання усіма працівниками, задіяними у навчальному процесі. Запроваджується через процедури узгодження із усіма уповноваженими особами і затвердження на рівні ректора вузу. Окремі документи проходять через попередній розгляд Вченої ради академії. Чинність таких документів $€$ тривалою, зміни і доповнення можуть вноситися лише у випадку появи нових нормативно-правових актів, що регламентують діяльність профільних інституцій. Нормативно-методичне забезпечення слугує фундаментом для створення інших науково-методичних документів.

Організаційно-методичне забезпечення співвідноситься із тими документами, які у нашій авторській класифікації входять до групи планових науково-методичних документів. Метою цієї категорії забезпечення, як це відображено у самій назві, є проектування, конструювання, планування, здійснення і контроль навчального процесу. Тож в основі організаційнометодичного забезпечення є окремі управлінські процеси. Укладачами даної категорії документів виступають керівники факультетів, допоміжний склад 3 
числа працівників навчального відділу. Пропозиції щодо формування окремих документів цієї групи (зокрема, тематичні плани) надаються кафедрами. Регламентація даного напряму діяльності відбувається відповідно до нормативних документів Міністерства освіти і науки України, a також положення про організацію навчального процесу певного юридичного навчального закладу. Термін дії документів обмежується періодом навчання фахівців за певним рівнем вищої освіти (навчальний план, графік навчального процесу), навчальним роком (робочий навчальний план) або семестром (тематичний план, розклади занять). Імперативний характер документів зумовлюється грифами затвердження і підписами відповідних керівників.

Принагідно хочемо оговорити, що ми не включаємо до організаційнометодичного забезпечення окремі робочі документи такі, як журнал академічної успішності, екзаменаційні відомості тощо, через їх принципово інші функції, а саме - засвідчення наявних результатів освітньої діяльності.

Предметно-методичне забезпечення є ядром усього науковометодичного забезпечення, тому що саме воно дозволяє формулювати i реалізовувати зміст освіти, супроводжувати аудиторну, індивідуальну i самостійну роботу. Сюди згідно із запропонованою нами класифікацією ми включили групу документів науково-методичного супроводження навчального процесу. Обов'язок створювати й постійно оновлювати даний вид забезпечення безпосередньо покладається на науково-педагогічних працівників. При цьому можуть використовуватися як форми групової роботи (наприклад, авторські колективи посібників), так і індивідуальної роботи (план-конспект занять, фондова лекція тощо).

Упровадження в навчальний процес інформаційних технологій потребує від науково-педагогічних працівників певного рівня володіння комп 'ютером, що дозволяє створювати електронні варіанти документації, здійснювати презентацію лекційного матеріалу. Проте у більш складних випадках, наприклад, при підготовці мультимедійних підручників, посібників, машинних тестових завдань, на допомогу викладачам повинні приходити фахівці технічного профілю, які знаються на комп“ютерно орієнтованих дидактичних системах.

При створенні предметно-методичного забезпечення науковопедагогічні працівники діють відповідно до нормативних актів $\mathrm{MOH}$ України, положень конкретного навчального закладу. Документи цієї групи характеризуються широким діапазоном відносно їхньої імперативності. Так, навчальні програми дисциплін $\epsilon$ обов'язковими до виконання усіма викладачами кафедр. У той же час плани-конспекти занять дають можливість зробити процес викладання творчим, персоніфікувати його відповідно до індивідуального стилю кожного окремого викладача. Так само підручники i посібники можуть (і мають!) вирізнятися власним баченням автора, містити його інтерпретацію певних наукових фактів.

Слід замітити, що, на жаль, досить розповсюдженою у підготовці правознавців є практика, коли посібники по суті відтворюють тексти тих чи 
інших законодавчих актів, не враховують особливості навчально-наукового підстилю наукового стилю літературної мови. Це означає, що тим, хто збирається писати навчальні посібники, слід додатково опановувати педагогічні й лінгвістичні засади науково-методичного забезпечення.

Повертаючись до характеристики вказаної категорії документів, зазначимо, що спостерігається широка варіативність і щодо терміну їх дії. Якщо посібники і підручники створюються на достатньо тривалий період, то плани-конспекти занять, тематика курсових, дипломних і магістерських робіт, завдання для індивідуальної i самостійної роботи повинні оновлюватися постійно. Так само неперервно мають доповнюватися i переглядатися ті матеріали 3 практики, які потім будуть використовуватися для створення фабул ділових i рольових ігор, навчальних тренінгів, ситуаційних завдань тощо.

С свої особливості у предметно-методичного забезпечення в плані їх затвердження. Окремі документи загалом не потребують затвердження (припустимо, ситуаційні завдання, матеріали проведення ділових ігор), другі (наприклад, плани-конспекти занять) затверджуються завідуючим кафедрою, інші (тематика курсових, дипломних і магістерських робіт) розглядаються на засіданні кафедри і затверджуються іiі рішенням. Запровадження навчальних (робочих навчальних) програм, рекомендація до друку навчальних посібників і підручників виходить за межі юрисдикції кафедри і відносяться до компетенції вченої ради вищого навчального закладу. Надання відповідних грифів навчальним підручникам і посібникам відбувається згідно 3 нормативними документами МОН України, а значить тексти затверджуються рішенням установи, що передбачена цими документами.

Безумовно, з предметно-методичними матеріалами мають справу усі учасники навчального процесу. Саме від цієї категорії науково-методичного забезпечення найбільшою мірою залежить якість підготовки фахівців.

Інформачійно-методичне забезпечення створюється 3 довідковоінформаційною метою, поширення першоджерел. Так, в якості інформаційно-методичного забезпечення в рамках діяльності вищого юридичного навчального закладу можна розглядати тексти кодексів, законів, підзаконних актів, відомчу нормативну базу. Особливість даного виду текстів полягає в тому, що їх автори (укладачі) створювали ці тексти у парадигмі законотворчої (нормотворчої) діяльності 3 метою регулювання правозастосовчої практики і навряд чи мали на увазі використання цих текстів в якості навчальних. Проте феномен підготовки правознавця полягає в тому, що усі фахові навчальні посібники і підручники базуються на використанні й тлумаченні нормативно-правових актів. Тому i здобуття фахової освіти майбутнім правником потребує звернення до першоджерел, адже саме із цими актами йому треба буде працювати у майбутньому, звіряючись 3 ними здійснювати кваліфікацію злочинів, здійснювати наглядову практику тощо.

До групи інформаційно-методичного забезпечення ми також відносимо енциклопедії, довідники, практичні посібники тощо. Ці матеріали 
дозволяють сформувати понятійно-категоріальний апарат фахових знань, розширити кругозір особи.

Особливістю інформаційно-методичного забезпечення $є$ те, що воно може зазначатися у списку літератури у програмах дисциплін, лекціях, планах семінарських занять, проте абсолютно зрозуміло, якщо автори (укладачі) текстів не працюють у даному вищому навчальному закладі, ніякого затвердження ці матеріали не проходять. Їх використання залишається на рівні рекомендацій науково-педагогічних працівників або ж власного розсуду того, хто навчається.

До інформаційно-методичного забезпечення в якості складового елемента ми включили бібліотечно-методичне забезпечення, адже саме на бібліотеки покладається функція зосередження і розповсюдження навчальної інформації. МОН України чітко встановлює нормативи щодо забезпечення студентів навчальними підручниками i посібниками, без чого унеможливлюється ліцензування освітньої діяльності певного вишу. Ми погоджуємося із Н.П.Пасмор в тому, що інтегративна суть бібліотечнометодичного забезпечення здійснюється в поєднанні документної, інформаційної та когнітивної складових. [9, с.6] Проте не можна скидати 3 рахунків, що із розповсюдженням інтернет-технологій настав час говорити про віртуальні бібліотеки, в яких зосереджуються електронні й мультимедійні підручники, аудіолекції і відеолекції. $€$ певні проблеми щодо збереження у таких умовах авторських прав, проте саме за таким забезпеченням майбутнє.

Виробничо-методичне забезпечення зазвичай зосереджується у лабораторіях, спеціалізованих навчальних аудиторіях. Воно передбачає наявність певних муляжів, макетів, моделей, імітацію робочого місця. Наприклад, при підготовці кадрів для слідства використовується так зване АРМС (автоматизоване робоче місце слідчого), яке максимально відповідає вимогам квазіпрофесійної діяльності. Виробничо-методичне забезпечення слугує відпрацюванню на практиці тих навичок, які у подальшому знадобляться у безпосередній професійній діяльності. Саме завдяки цьому виду науково-методичного забезпечення в умовах вишу найповніше реалізується дидактичний принцип поєднання теорії і практики. Це дозволяє студентові, приходячи на стажування, мінімізувати період адаптації до умов роботи.

Специфіка даного виду забезпечення полягає в тому, що воно у більшості випадків потребує певних матеріальних витрат. Це означає, що відбувається не стільки затвердження самих матеріалів, скільки визначення доцільності їх придбання, здійснення тендерних процедур тощо. Від науковопедагогічних працівників потребується, з одного боку, самостійно опанувати володіння цими інструментами, 3 іншого - створити належні предметнометодичні матеріали 3 метою раціонального використання у навчальному процесі.

Оскільки цей вид науково-методичного забезпечення найтісніше пов 'язаний із матеріальною стороною навчального процесу, то і придбання 
певних муляжів, макетів, діючих моделей, автоматизованих систем застосовуються достатньо тривалий час.

Використання виробничо-методичного забезпечення не $є$ жорстким імперативом, разом 3 тим саме воно в багатьох випадках визначає рівень матеріально-технічної бази вищого навчального закладу, допомагає прищеплювати інтерес до майбутньої професійної діяльності, надавати праксеологічні моделі раціональної поведінки працівника.

Висновки. Підводячи підсумки, зазначимо, що науково-методичне забезпечення освітнього процесу у вищих юридичних навчальних закладах являє собою складний інтегративний комплекс, який об‘єднує суб“єктноорганізаційні, цільові, діяльнісні, контрольні компоненти, матеріальні та ідеальні об‘єкти. Його розвиток зумовлюється як зовнішніми, так і внутрішніми чинниками. Забезпечення належної якості вищої освіти унеможливлюється у разі відсутності науково-обгрунтованих концептуальних уявлень щодо даного виду методичної діяльності та його ефективної реалізації.

\section{ЛІТЕРАТУРА}

1. Владимирська Є.Ю. Науково-методичне забезпечення якості дистанційного навчання у технічному університеті: автореф. дис.. канд. пед. наук: 13.00.01 / С. Ю .Владимирська ; АПН України. Ін-т вищ. освіти. - К., 2006. - 20 с.

2. Годованюк Т.Л. Методика індивідуального навчання історії математики студентів педагогічних університетів: автореф. дис... канд. пед. наук: 13.00.02 / Т. Л. Голованюк ; Нац. пед. ун-т ім. М.П.Драгоманова. - К., 2009. - 20 с.

3. Павленко О.О. Формування комунікативної компетенції фахівців митної служби в системі неперервної професійної освіти: автореф. дис... д-ра пед. наук : 13.00 .04 / О. О. Павленко ; Луган. нац. ун-т ім. Т. Шевченка. - Луганськ, 2010. - 44 с.

4. Пуліна A.A. Система організаційно-методичного забезпечення педагогічного проектування в загальноосвітніх навчальних закладах: автореф. дис... канд. пед. наук : 13.00.01 / А. А. Пуліна ; РВНЗ «Крим. гуманіт. ун-т» (м.Ялта). - Ялта, 2011. - 20 с.

5. Савченко Г.О. Формування готовності майбутніх фахівців банківської справи до аналітичної діяльності засобами моделювання: автореф. дис.. канд. пед. наук: 13.00 .04 / Г. О. Савченко ; Харк. Нац. пед. ун-т ім. Г.С.Сковороди. - Х., 2006. - 20 с.

6. Юрченко Ю.А. Формування військово-професійних умінь у студентів вищих медичних навчальних закладів: автореф. дис. канд. пед. наук: 13.00 .04 /Ю. А. Юрченко ; Нац. акад. Держ. прикордон. Служби України ім. Б. Хмельницького. - Хмельниц., 2006. $20 \mathrm{c}$.

7. Яворська Г.Х. Теоретичні та методичні засади формування соціальнопрофесійної зрілості курсантів вищих навчальних закладів МВС України: автореф. дис... д-ра пед. наук: 13.00.04 / Г. Х. Яворська ; Ін-т педагогіки і психології професійної освіти АПН України. - К., 2006. - 44 с.

8. Закон України «Про вищу освіту» від 01.07.2014 [Електронний ресурс] // http://zakon2.rada.gov.ua/laws/show/1556-18

9. Пасмор Н.П. Бібліотечно-інформаційне забезпечення самостійної роботи студентів вищих навчальних закладів юридичного профілю: Автореф. дис. канд. пед. наук: 07.00.08 / Н.П.Пасмор: Харк. держ. акад. культури. - Х., 2003. - 20 с. 
O.B. Топчий

\section{НАУЧНО-МЕТОДИЧЕСКОЕ ОБЕСПЕЧЕНИЕ ОБРАЗОВАТЕЛЬНОГО ПРОЦЕССА В ВЫСШЕМ ЮРИДИЧЕСКОМ УЧЕБНОМ ЗАВЕДЕНИИ}

Статья посвящена теоретическому обоснованию особенностей научнометодического обеспечения образовательного прочесса в высшем юридическом учебном заведении. Представлен авторский подход $к$ пониманию ключевого понятия. Проанализированы факторы, детерминирующие появление методического обеспечение нового поколения. Установлены уровни научно-методического обеспечения в соответствии с субъектами создания. Автор репрезентирует собственную классификачию видов научно-методического обеспечения, актуальных для высших юридических учебных заведений.

Ключевые слова: образовательный прочесс; научно-методическое обеспечение; высшее юридическое учебное заведение; Закон Украины «О высшем образовании».

O.V. Topchiy

\section{SCIENTIFIC-METHODOLOGICAL SUPPORT OF EDUCATIONAL PROCESS IN THE HIGHER LAW SCHOOLS}

The article is devoted to theoretical substantiation of the features of scientific and methodological support of educational process in higher legal education. The author gives a definition of the key concept - a set of information materials (text, graphics, media), which provide the needs of the subjects of the educational process in the data, which is the purpose and content of education, and aimed at optimal achievement of learning outcomes. This article contains a list of factors that determine the need for a new generation of methodological support. The author presents a classification of methodical support, which includes projective, regulatory, scientific and methodical planning documents as well as documents of methodological support of the educational process, and visual materials. The researcher drew attention to the increased role of individual learning, self-education, information technology, the gradual introduction of Western models of organization of educational process. The author draws attention to the fact that the texts of legislative acts acquire the ability to be information and teaching materials that are used in higher legal education. The key idea is that the scientific and methodological support should be considered at three levels: the normative, theoretical and practical.

Keywords: educational process; scientific and methodological support; higher legal education institution; the Law of Ukraine "On Higher Education". 